\title{
Tax Loss Amortization of Companies in Slovakia
}

\author{
Anna Bánociová and Slavomíra Ťahlová * \\ Department of Finance, Faculty of Economics, Technical University of Košice, B. Němcovej 32, \\ 04001 Košice, Slovakia; anna.banociova@tuke.sk \\ * Correspondence: slavomira.tahlova@tuke.sk; Tel.: +421-911-242-248
}

Received: 9 September 2020; Accepted: 13 October 2020; Published: 14 October 2020

\begin{abstract}
The purpose of this article is to research how companies optimize income tax with the ambition to maintain the achieved sales and profits at the highest possible level. Its purpose is to find out whether companies in Slovakia compensate for higher tax liability by tax loss amortization to reduce their income tax payable. Based on the review of literature from the field of legislation concerning the tax loss amortization by using the descriptive statistics of selected corporate and tax indicators, the companies are monitored in order to capture their behavior in paying income tax. The methods of deduction and synthesis are used in this article. The observed corporate and tax indicators are focusing on the relationship between the tax liability arising from corporate income tax, amortized tax losses, and the amount of tax payable in Slovakia in the period from 2015 to 2018. Tax loss can be considered as a tool for tax optimization, which is used by companies in all countries of the European Union, while the scope of its applicability is often limited by a time horizon. The amortization of tax losses has an impact on the amount of tax levied and the subsequent income tax payable, while the possibility to use this tool of tax optimization is influenced by the changing legislation in the period under review.
\end{abstract}

Keywords: tax loss; tax loss amortization; corporate income tax; tax optimization

\section{Introduction}

In general, it is possible to consider the occurrence of a tax loss as an unreasonable and unconsidered decision making of a business entity, but in many cases, the tax loss is caused intentionally as a business management activity. The impact of taxation, especially corporate income taxation, on corporate finances has been the subject of research since the last century, when Modigliani and Miller (1963) began to address this issue. Nevertheless, there is a little literature which deals with the relationship between the country's tax legislation and corporate finance, their profits and the amount of their taxation.

A significant problem in the comparison of individual countries is the constantly changing legislation and the heterogeneity of tax laws responding to the subjectivity of states and their strategy in creating the business environment. However, there are several studies dealing with the issue of tax losses. Altshuler et al. (2009) examined a ratio of tax losses to rate of return in the period from 1982 to 2004 on a sample of American companies. According to the authors, tax losses increased in the observed period due to a decrease in average rates of return and not due to an increase in the difference between taxable income and the measures applied to stimulate economic benefits. They did not confirm the impact of the existence of the possibility of claiming tax losses on the profitability of companies. A positive relationship between corporate taxation, applied tax losses and the amount of debt in emerging markets was observed by Delcoure (2007) and Bayrakdaroglu et al. (2013). A negative relationship was observed by Booth et al. (2001).

Evaluating the financial situation of companies is complex and multidimensional. How do business entities in Slovakia optimize income tax with the ambition to maintain the achieved sales and profits at the highest possible level? 
The purpose of this article is to determine whether companies in Slovakia compensate the higher tax liability through a tax loss amortization to reduce their income tax payable and thus ensure a higher profit. The article consists of the following parts: the theoretical part in the form of a literature review is devoted to explaining the possibilities of tax loss amortization in Slovakia and in the Visegrad Group countries (hereinafter referred to as the V4 countries) and describes the situation in selected member states of the European Union. In order to approach the analytical part, the theoretical part further deals with the explanation of legislative differences in the years from 2015 to 2020 in Slovakia. The methodological part describes the reasons for the examined indicators selection and the nature of the sample of companies and determines the hypothesis and the possibilities of its investigation. The results of the analytical part focus on the relationship between corporate income tax liability, amortized tax losses, and the amount of tax payable in Slovakia in the period from 2015 to 2018. The discussion introduces the reasons for the implemented legislative changes in the period from 2015 to the present in the given territory.

\section{Literature Review}

In the economic literature, a tax loss is defined as a net operating loss that is the opposite of net profit (Murray 2019; OECD 2011). From the legislative point of view, the tax loss represents the difference by which tax expenses exceed taxable income, while respecting the substantive and temporal scope of taxable income and tax expenses (Act No. 595/2003 on Income Tax, hereinafter referred to as the Slovak Income Tax Act). Companies report a tax loss if the deductions of expenses are higher than the total income according to the tax reporting rules in the relevant state jurisdiction (Australian Government 2020; Bragg 2018). If a taxpayer reports a tax loss and the tax legislation allows it to be deducted from the tax base, it allows the taxpayer to reduce his/her tax liability. A tax loss carried forward is a form of profit compensation in order to reduce all future taxes (Toder and Viard 2016; Florescu et al. 2016; Alworth and Arachi 2001).

The economic importance of tax avoidance has been addressed in recent studies (European Commission 2017). The terms tax avoidance and aggressive tax planning both describe behavior against the spirit of the law to reduce the tax liability. The tax planning structures can reduce the pre-tax profit via a reduction in financial profits and losses. Consequently, we may see different patterns of effective tax rate and profitability measures.

The valid Slovak Income Tax Act allows business entities to deduct the reported tax loss from the tax base and thus reduce the tax liability in the immediately following tax period. The possibilities of tax loss amortization are relatively homogeneous for natural persons and legal entities in the V4 countries (see Table 1).

Table 1. Tax loss amortization in business entities of the V4 countries.

\begin{tabular}{ccc}
\hline V4 country & Natural person & Legal entity \\
\hline Slovakia & $\begin{array}{c}\text { Tax losses can only be amortized from } \\
\text { enterprise income and self-employment; } \\
\text { Amortization period: four years in the } \\
\text { amount of } \frac{1}{4} \text { per year. }\end{array}$ & $\begin{array}{c}\text { Amortization period: four years in } \\
\text { the amount of } \frac{1}{4} \text { per year. }\end{array}$ \\
\hline Czech Republic & Amortization period: five years continuously. \\
\hline Hungary & $\begin{array}{c}\text { Amortization period: until taxable period } 2015 \text { can be tax losses amortized for } \\
\text { five years in full amount, and after this period, they can be amortized up to only } \\
50 \% \text { of the tax base. }\end{array}$ \\
\hline Poland & Amortization period: tax losses can be amortized for following five years, each \\
year can be deducted 50\% of the loss.
\end{tabular}


In the case of the V4 countries, the Slovak tax legislation distinguishes between the amortization of tax loss for natural persons and legal entities, primarily due to the subject of taxation. In the Czech Republic, it is possible to amortize a tax loss for five years continuously. In Hungary and Poland, the same methods of amortization of tax losses are applied; tax losses reported in the taxable period 2015 can be amortized for five years and after this period they can be amortized up to only $50 \%$ of the tax base.

In the case of the member states of the European Union, Croatia and Bulgaria apply the possibility to deduct the tax loss without further additional restriction for a period of five years. Another group of tax loss amortization is provided by the legislation valid in Belgium, Italy, Spain, and Slovenia. Tax laws allow business entities to amortize the tax loss without restrictions, with the exception of Slovenia, where the deducted amount of tax loss can be only up to $50 \%$ of the tax base. In Portugal, tax losses can be deducted up to 12 years. The Portuguese distinguish between a tax loss recorded till year 2016, as the tax loss for the next 12 years is deducted during this period, and a tax loss recorded from year 2017, since they reduce the period of the tax loss amortization to a five-year period. In the case of other countries (outside the member states of the European Union), there is a possibility of deducting tax loss in different periods, most often in the range of three to ten years.

If a company quantifies an accounting loss, it does not mean that it will also report a tax loss. The amortization of tax losses of an enterprise accounting in the double-entry bookkeeping system is based on the economic result, which is determined as the difference between income and expenses (Khansalar and Kashefi-Pour 2020; Fellingham 2018). There is a possibility to amortize tax losses from the tax base in the future, which contributes to income tax savings, recovery, stabilization, and further growth of the company (Benko 2014; Vanková 2018).

In case of a low tax base, the company did not use the option of the tax loss amortization in a full exploitation, and the unapplied part of the tax loss remained unused. In Slovakia, the amortization of the tax loss was limited mainly in time. It was only since 2014 that there was a change in the method of deducting tax losses that the company reported for the period from 2010 to 2013 . From the previously existing possibility of a tax loss amortization in any tax period and in any amount during seven tax periods, it was possible only to amortize a tax loss evenly over the four tax periods. The change in the length of tax loss depreciation led companies to an increase of their income tax payment. Significant changes in the legal regulation of the tax loss deduction caused the company to narrow its possibilities of optimizing its tax liability. From 2014 to 2019, it was possible to amortize tax losses evenly over the four tax periods by only a proportional part, which could have been a maximum of one quarter. The company paid the rest in the form of a tax liability. The amendment to the Slovak Income Tax Act brought new rules for deducting the tax loss reported for the tax period of year 2020, which affected the following elements:

- The deduction period is extended from four immediately consecutive tax periods to five immediately consecutive tax periods;

- The limitation of the deducted tax loss amount is changed to the level of a maximum $50 \%$ of the reported tax base, from which the tax loss is deducted in the submitted statement of tax income (see Table 2). 
Table 2. Legislative specifics of tax loss amortization in Slovakia.

\begin{tabular}{|c|c|c|c|}
\hline & $\begin{array}{l}\text { Deduction of Tax Loss until } \\
\text { 31 December } 2013\end{array}$ & $\begin{array}{c}\text { Deduction of Tax Loss from } 1 \\
\text { January } 2014\end{array}$ & $\begin{array}{l}\text { Deduction of Tax Loss } \\
\text { from } 1 \text { January } 2020\end{array}$ \\
\hline 2009 & $\begin{array}{l}\text { Possible in any amount for a } \\
\text { maximum of five immediately } \\
\text { consecutive tax periods, } \\
\text { beginning with the tax period } \\
\text { after the tax period for which } \\
\text { the tax loss was recognized, up } \\
\text { to the amount of the tax base. }\end{array}$ & $\begin{array}{l}\text { Possible in any amount for a } \\
\text { maximum of five immediately } \\
\text { consecutive tax periods, } \\
\text { beginning with the tax period } \\
\text { after the tax period for which } \\
\text { the tax loss was recognized, up } \\
\text { to the amount of the tax base. }\end{array}$ & \\
\hline 2010-2013 & $\begin{array}{l}\text { Possible in any amount for a } \\
\text { maximum of seven } \\
\text { immediately consecutive tax } \\
\text { periods, beginning with the } \\
\text { tax period after the tax period } \\
\text { for which the tax loss was } \\
\text { recognized, up to the amount } \\
\text { of the tax base. }\end{array}$ & $\begin{array}{l}\text { The sum of unclaimed tax losses } \\
\text { for these tax periods may be } \\
\text { deducted on a straight-line basis } \\
\text { over four consecutive tax } \\
\text { periods, up to a maximum of the } \\
\text { tax base, the first tax period } \\
\text { beginning on } 1 \text { January } 2014 \text { at } \\
\text { the earliest. }\end{array}$ & \\
\hline 2014-2019 & & $\begin{array}{l}\text { Possible on a straight-line basis } \\
\text { for a maximum of four (or more } \\
\text { precisely three or two) } \\
\text { consecutive tax periods (based } \\
\text { on taxpayer's decision), starting } \\
\text { with the tax period for which the } \\
\text { tax loss was recognized, up to } \\
\text { the amount of the tax base. }\end{array}$ & \\
\hline 2020 & & & $\begin{array}{l}\text { Possible unevenly over } \\
\text { five consecutive tax } \\
\text { periods, starting with the } \\
\text { tax period for which the } \\
\text { tax loss was recognized, } \\
\text { up to a maximum of } 50 \% \\
\text { of the tax base. }\end{array}$ \\
\hline
\end{tabular}

This table presents the tax losses amortization of companies in Slovakia from 2009 to the present (excluding public companies and limited partnerships) based on the Slovak Income Tax Act. Tax legislation affecting income tax did not directly limit companies in the amount of deduction of tax loss until 2020.

\section{Materials and Methods}

The purpose of the article is to find out whether companies in Slovakia compensate for higher tax liability by tax loss amortization to reduce their income tax payable and thus ensure higher profits. Based on theoretical knowledge, the following hypothesis is developed:

Hypothesis 1 (H1). Amortization of tax losses in companies has an impact on the amount of tax liability and income tax paid.

The analytical part investigates the relationship between the tax liability arising from corporate income tax, amortized tax losses and the amount of tax payable. The object of the research is companies in Slovakia.

In Slovakia, the total number of companies according to the Statistical Office of the Statistical Office of the Slovak Republic (2020) is 241,920 (average), while the most numerous group consists of trading companies. The selection and character of the basic research sample, which is observed in the period from 2015 to 2018 , consists of 213,399 business entities, which represents $89.80 \%$ of the total number of companies. The sample corresponds to their distribution in Slovakia and can therefore be considered representative in terms of size, heterogeneity, and method of data collection (see Table 3). 
Table 3. Situation of companies in Slovakia.

\begin{tabular}{cccccc}
\hline & $\mathbf{2 0 1 4}$ & $\mathbf{2 0 1 5}$ & $\mathbf{2 0 1 6}$ & $\mathbf{2 0 1 7}$ & $\mathbf{2 0 1 8}$ \\
\hline Total number in Slovakia & 259,055 & 207,655 & 228,110 & 248,945 & 265,835 \\
$\quad$ Researched sample & - & 193,221 & 210,766 & 219,466 & 230,143 \\
Western Slovakia (WS) & 152,300 & 124,751 & 137,897 & 148,963 & 157,858 \\
$\quad$ Researched sample of & - & 118,354 & 129,921 & 135,018 & 140,548 \\
$\quad \begin{array}{l}\text { enterprises in WS } \\
\text { Central Slovakia (CS) }\end{array}$ & 52,091 & 41,137 & 44,830 & 50,019 & 54,068 \\
$\quad$ Researched sample of & - & 37,269 & 40,286 & 42,214 & 44,819 \\
$\quad$ enterprises in CS & - & 41,767 & 45,383 & 49,963 & 53,909 \\
Eastern Slovakia (ES) & 54,664 & & 40,559 & 42,234 & 44,776 \\
Researched sample of & - & 37,598 & & &
\end{tabular}

This table summarizes the total number of companies based on the date of the Statistical Office of the Statistical Office of the Slovak Republic (2020) and Finastat (2020) in Slovakia.

The country-level descriptive statistics of the specific company-level indicators give a first indication of the relative importance of the various tax planning structures. As mentioned by the European Commission (2017) or McGuire et al. (2016), looking at the descriptive statistics of the underlying ratios by country and company type allows us to broadly quantify the average effect of tax planning activities. The aggregating the number of companies shows to which extent a country is affected by structure tax optimization. Although the main methodological tool is descriptive statistics, the results bring new information in an international context because they inform about the way of thinking of entrepreneurs in a given territory, the relationship between individual tax optimization options, the usage of tax loss in the country, and changing tax legislation not only for enterprises located in the territory and for foreign investors.

Descriptive statistics is also used in other studies focused on the payment of taxes of individual entities. Siekelova et al. (2019) focused on the analysis of the profitability of enterprises as well as on the identification of indicators that significantly influence the rate of profit. The authors contributed to identification of main indicators of profit creation. The analysis of the profitability was conducted using methods of descriptive statistics. The authors considered that the amount of corporate income tax could not affect the change in EBIT. European Commission (2017) calculates for the effective tax rate measure as the ratio between tax liabilities and EBIT. Krajňak (2020) used a descriptive statistic to assess a taxpayer tax liability, tax optimization, and tax deductions depending on the amount of income of natural persons in one of the regions of the Czech Republic. As the author writes, the statutory or effective tax rate is decisive in choosing the optimal method of income taxation, but it is also important to assess the significance of other criteria and comprehensively evaluate the legislation, the amount of income, or social factors that may significantly affect tax liability. With the intention to point out the basic differences and similarities in the examined data set, Krajňak (2020) shows how often the taxpayer's tax liability changes in connection with tax reliefs and social security contributions. The taxpayer or the subjects of decision making optimize their tax liability by making tax payments as low as possible. The relationship between the change in the tax legislation, tax savings, and the financing of the company's long-term debts was examined by Malikova and Cernikova (2014). The authors used the descriptive statistics to focus on companies in the Czech Republic, and they discussed the advantages and disadvantages of financing the business activities in terms of tax legislation. The results were demonstrated in a case study, where they describe possible tax savings with the help of the level of amortized tax loss.

The performed analysis uses data from statements of tax income of legal entities structured by tax authorities, with information about the number of them, tax base, tax loss and deduction of tax loss. The time horizon is the period from 2015 to 2018 due to the availability of data and the closure of the time period. The analytical part is divided into two consecutive parts, which complement each other. The analysis adopts generally valid principles for identifying the following variables: 
- Indicators of corporate character:

$\circ \quad$ change in sales volume growth in \%;

$\circ \quad$ change in profit volume growth in \%;

$\circ \quad$ change in EBITDA volume growth in \%.

- Tax indicators:

$\circ \quad$ income tax payable in $€$;

$\circ \quad$ tax paid in $€$;

- statutory and effective corporate tax rate in \%;

- the absolute value of the tax loss in $€$ points out the amount of funds that companies had the opportunity to amortize from the tax base. It is assumed that, by year 2017, the amount of amortized tax loss will increase due to the current legislation, which allowed in the period from 1 January 2014 to apply the sum of unapplied tax losses for tax periods evenly over four immediately consecutive tax periods and up to the tax base. Since 2020, the amount of amortized funds is expected to decrease due to the changing legislation, which allows the tax loss to be amortized unevenly over a period of five years, but only up to $50 \%$ of the tax base.

- Situation of business entities:

- the number of those who reduce the tax base by amortizing the tax loss and the absolute value of the variable points out the applicability of the tax loss. The assumption is that the number of entities using tax loss amortization will be the highest in 2017, as it is the last period that allows to take into account the legislation from year 2014.

The first part of the analysis shows the situation of companies operating in Slovakia, structured by the volume of their income tax payable. A large group of characteristics of the examined object (change in sales volume growth in \%, change in profit volume growth in \%, change in EBITDA volume growth in \%, statutory and effective tax rates in \%) with one aggregate indicator (payable income tax, tax paid) can capture a multidimensional phenomenon in the form of financial situation of companies in the context of tax due. The ratio of income tax to the company's gross profit is also often monitored, which is indicated by the effective average tax rate in \%.

The second part of the analysis is carried out through the observation of companies (the absolute value of the tax loss, situation of business entities as the number of those who reduce the tax base by amortizing the tax loss) in individual regions of Slovakia at the NUTS 2 level. The reason for dividing them into three regions is the different specification of the level of employment, business opportunities or barriers. As of 1 January 2012, eight tax offices were established in the district offices and one office for selected tax entities with their registered office in Bratislava. The NUTS 2 area is divided into three groups:

- Western Slovakia includes the tax offices of Bratislava, Trnava, Trenčín, and Nitra;

- Central Slovakia includes the tax offices of Žilina and Banská Bystrica;

- Eastern Slovakia includes the tax offices of Prešov and Košice.

\section{Results and Discussion}

Tax optimization is carried out in various ways, such as amortizing tax losses, shifting taxable income and expenses between tax periods, maximizing applicable tax expenditures, using taxpayer status, or using other tax benefits for the development of the business environment (Seneši 2020; Bazo et al. 2019; Pfeifer and Yoon 2016; Armstrong et al. 2012; Post and Stals 2012). As can be seen, there are many facts with an impact on the final total tax. It is clear that the changes of the total tax liability were 
not only influenced by the increase of all items. It means that the impact of indicators' changes could be positive or negative.

The number of companies, the amount of their tax payable, and the direction of corporate and tax indicators have changed in Slovakia during the period of five years. Positive changes in the development of indicators did not demonstrate an increase of income tax paid. Proven reasons may be several legislative changes that occurred in the observed period, e.g. in the form of the possibility of applying for the amortization of tax loss, the application of tax licenses, or the reduction of the statutory and effective tax rate.

Classical economic theories emphasize the indicators of corporate character, mainly the achievement of profit, as a fundamental goal of a business (Agarwal et al. 2018; Sion 2018). Modern theories consider achieving profit as one of the basic motivating factors, but no as the main goal of business (Jim Yeub and Myungkyu 2019; Olah et al. 2019). Over the last six years, companies in Slovakia have achieved a more significant increase in the volume of their profits (average year-on-year increase of $6.6 \%$ with a maximum value of $25.11 \%$ in year 2015), an increase in EBITDA index (average year-on-year increase of $6.1 \%$ with maximum value at $14.53 \%$ in year 2015), but only a slight increase in the amount of income tax paid (the average year-on-year increase is $3.6 \%$, with an extreme negative value of income tax at $-€ 84.64$ million in 2018 , which overall produced by $42.78 \%$ of companies). From the tax indicators in our analysis, we observe payable income tax payable, tax paid, statutory and effective corporate tax rates, and the absolute value of the tax loss. Lisztwanova and Ratmanova (2018) analyzed the assessment of factors influencing the financial corporate income tax liabilities in Czech. Based on the impact of changes of the statutory tax rate, the authors emphasized the impact of reducing tax base and the influence of the tax discounts on the total tax liability. In the case of examining the individual sectors in the country, the authors point to the fact that in almost all observed sectors, the level of statutory tax rate is the third factor that the most affects the total tax liability, right after the adjusted tax base and tax loss. The statutory corporate tax rate was set at $22 \%$ until the tax period of 2016; however, from the beginning of the tax period of 2017 until now, it is set at $21 \%$. General tax theory assumes that its declining nature leads to an increase in the volume of tax income to the state budget (Djankov et al. 2010; Clausing 2007; Fox and Luna 2005). Generally, it can be claimed that the decrease of statutory tax rate causes a decrease of the total tax liability. The effective corporate tax rate, which includes the statutory tax rate on corporate income and other aspects of tax systems determining the total amount of effectively paid taxes, is used for more accurate representation of taxpayer's tax liability. Kosturikova (2016, p. 314) examined the dependence of the effective taxation on the corporate income tax rate in the European Union. The author states that "a change in the effective corporate taxation is caused by a change in the statutory tax rate (more than $98 \%$ ). An increase in the statutory corporate tax rate by $1 \%$ results in an increase of the effective average tax rate on average by $0.78 \% . "$ The effective corporate tax rate also acquires the declining character in selected periods. Looking at the period of 2016 or 2017, it is possible to assume that the development agrees with the economic theory. A similar relation is stated in the findings of Zeng (2010) or Dyreng et al. (2008). Zeng (2010) researched a long-term income tax liability for Chinese public corporations. Based on the analysis, the author states that there is a large number of factors influencing the effective tax rates; however, the 10-year effective tax rates are considerably lower than the statutory tax rate (see Table 4). 
Table 4. The data characterizing the financial situation of the companies in the years from 2014 to 2018.

\begin{tabular}{|c|c|c|c|c|c|}
\hline & 2014 & 2015 & 2016 & 2017 & 2018 \\
\hline Sample number of companies in SR & 177,517 & 190,501 & 198,352 & 207,865 & 218,936 \\
\hline Change of sales volume growth & - & $8.64 \%$ & $1.08 \%$ & $7.86 \%$ & $8.67 \%$ \\
\hline Change of profit volume growth & - & $25.11 \%$ & $2.38 \%$ & $7.73 \%$ & $1.27 \%$ \\
\hline $\begin{array}{l}\text { Change of EBITDA volume growth } \\
\text { Income tax payable of companies }\end{array}$ & - & $14.53 \%$ & $2.08 \%$ & $6.57 \%$ & $1.35 \%$ \\
\hline $\begin{array}{l}\text { Negative to zero tax (million } € \text { ) } \\
\text { (\% of companies reporting this tax) }\end{array}$ & $\begin{array}{l}-119.26 \\
(15.91 \%)\end{array}$ & $\begin{array}{c}-4.82 \\
(10.95 \%)\end{array}$ & $\begin{array}{c}-1.62 \\
(11.08 \%)\end{array}$ & $\begin{array}{c}-1.42 \\
(10.98 \%)\end{array}$ & $\begin{array}{c}-84.64 \\
(42.78 \%)\end{array}$ \\
\hline$€ 1-2880$ (million $€$ ) & 100.02 & 111.44 & 114.92 & 120.26 & 65.84 \\
\hline (\% of companies reporting this tax) & $(64.12 \%)$ & $(66.31 \%)$ & $(66.13 \%)$ & $(66.29 \%)$ & $(37.64 \%)$ \\
\hline$>€ 2880$ (million $€)$ & 2474.87 & 2679.75 & 2586.55 & 2635.68 & 2716.48 \\
\hline (\% of companies reporting this tax) & $(19.97 \%)$ & $(22.74 \%)$ & $(22.79 \%)$ & $(22.73 \%)$ & $(19.57 \%)$ \\
\hline Total tax paid (million $€$ ) & 1330.32 & 1415.95 & 1493.27 & 1563.60 & 1530.06 \\
\hline \multicolumn{6}{|l|}{$\begin{array}{l}\text { Applicable income tax rate of } \\
\text { companies }\end{array}$} \\
\hline Statutory corporate tax rates & $22 \%$ & $22 \%$ & $22 \%$ & $21 \%$ & $21 \%$ \\
\hline Effective corporate tax rates & $19.4 \%$ & $19.6 \%$ & $19.6 \%$ & $18.7 \%$ & $18.7 \%$ \\
\hline
\end{tabular}

This table shows the financial situation of companies in Slovakia, focusing on their segmentation by indicators of corporate and tax nature. Authors' own elaboration based on Finastat (2020) and Eurostat (2020).

Applying a tax loss from the previous periods is a legal way to influence the amount of tax liability. The amortization of the tax loss is not an obligation for the company but an opportunity to reduce the tax base (Demere et al.; Borg 2013). Lisztwanova and Ratmanova (2018) also consider the tax loss as one of the significant factors affecting the total corporate income tax in the Czech Republic. According to the authors, the tax loss is the second most important factor that affected the change in the overall tax liability. In most cases, the tax loss contributed to a decrease of year-over-year tax burden. The highest amount of tax loss deduction in absolute value was in western Slovakia in 2017. The deduction was claimed by the highest number of companies. In case of claiming the amortization of the tax loss in the observed period, it can be said that the highest total amount of the reported tax loss in all compared years was achieved in western Slovakia. The amount of funds were four times higher than in central and eastern Slovakia. This is partly due to the size of the territory and the number of monitored entities. The area brings a greater concentration of new and established companies with the prospect of achieving higher profits, greater business opportunities and faster-growing investments. Simultaneously, the territory is facing higher expenses and business costs. In 2018, a significant decrease in the form of reduction of amortized tax loss by $50.84 \%$ was observed in Central Slovakia. It is important to point out what legislative manner can be used to claim the tax loss. Its importance varies between the countries. Cooper and Knittel (2006) followed the tax reports of American corporations for a decade. Although $40-50 \%$ of companies used the tax loss in the form of loss carry-forward on the 10-year horizon, approximately $25-30 \%$ of companies never used it (companies ceased their operation). In addition, the use of loss carry-forward deductions often depends on the specific loss year. The correct timing of the tax loss usage in order to reduce the company's future tax payments was addressed by, e.g., McGuire et al. (2016) and Sarkar (2013). As the amount of the tax loss deduction developed in the individual tax periods, so did the number of companies that used the deductions and thus reduced their tax liability. The total number of companies benefiting from a reduction of tax liability through amortization of tax loss increased, mainly in 2016 (in western and central Slovakia), where the deduction of tax loss was claimed by $20.34 \%$ of all registered companies. The revenue implications of a full loss refund system are real and not easily dismissed. Under certain conditions, it has been noted that the steady state cost of a full loss refund system could be relatively small (Poddar 1991). "Because many tax losses are never used, full loss refundability would have a non-trivial impact on revenues. Moreover, a full loss refund system would dramatically increase the volatility of corporate income tax revenues. From the perspective of the taxing authority, 
this outcome may be especially undesirable as net revenues would decline during cyclical downturns when they are needed most" (Cooper and Knittel 2006, p. 654). From a legislative point of view, 2017 was the last year when it was possible to apply deductions from accumulated tax losses for the tax periods 2010-2013. The conducted survey shows that, as expected (in the given period, it was possible to deduct the sum of unclaimed tax losses from four immediately consecutive tax periods for the last time), the amount of deduction in 2017 was the highest in western Slovakia. From the point of view of the total corporate income tax payable, this tax incentive did not affect its volume. In the whole monitored amount of income, a growing development is observed, with the maximum value in 2017 at the level of $€ 1,563.60$ million. Cooper and Knittel (2006) argue that the outcome depends on the number of years a company is expected to be non-taxable (i.e. the size of a company's loss stock) and the degree of accelerated depreciation allowed under tax law (see Table 5).

Table 5. The data characterizing the tax situation of the companies from 2015 to 2018.

\begin{tabular}{ccccc}
\hline & $\mathbf{2 0 1 5}$ & $\mathbf{2 0 1 6}$ & $\mathbf{2 0 1 7}$ & $\mathbf{2 0 1 8}$ \\
\hline $\begin{array}{c}\text { Western Slovakia } \\
\text { Tax loss (million } € \text { ) }\end{array}$ & 420.392 & 485.500 & 493.310 & 266.493 \\
$\begin{array}{c}\text { Number of companies using tax } \\
\text { loss amortization }\end{array}$ & 24,073 & 25,814 & 27,043 & 24,089 \\
Total number of companies & 118,354 & 129,921 & 135,018 & 140,548 \\
$\quad$ Central Slovakia & 100.393 & 126.611 & 118.910 & 58.454 \\
$\quad$ Tax loss (million $€$ ) & 7535 & 8039 & 8365 & 7645 \\
Number of companies using tax \\
$\begin{array}{c}\text { loss amortization } \\
\text { Total number of companies }\end{array}$ & 37,269 & 40,286 & 42,214 & 44,819 \\
$\quad$ Eastern Slovakia & 87.792 & 104.012 & 99.013 & 65.556 \\
$\quad \begin{array}{c}\text { Tax loss (million } € \text { ) } \\
\text { Number of companies using tax }\end{array}$ & 7380 & 7990 & 8435 & 7644 \\
$\quad \begin{array}{c}\text { loss amortization } \\
\text { Total number of companies }\end{array}$ & 37,598 & 40,559 & 42,234 & 44,776 \\
Total number of companies & 193,221 & 210,766 & 219,466 & 230,143 \\
\hline
\end{tabular}

This table shows the information from the statements of tax income of the observed sample of companies (specified in more detail in Table 3). It provides information about the amount of the amortized part of the tax loss of all companies in western, central, and eastern Slovakia. In addition to the amount of tax loss deduction in individual tax periods, it also shows the number of companies that have used the option of reducing the tax base by the tax loss amortization. Authors' own elaboration based on Finastat (2020).

In order to narrow the possibilities of tax optimization, there were new adjustments made in the rules of deducting tax losses in 2020. The reason for this was the finding that a significant part of companies (despite the growing volume of tax paid in the long run) did not pay any tax into the state budget and the number of companies with zero tax liability increased. The new tax loss amortization conditions valid since 2020 for tax losses imposes a limit on the deduction of tax loss to a maximum of $50 \%$ of the tax base, but ultimately, the company deducts more from the tax base after five years. In case of adopted legislative changes valid since 2020 concerning the amortization of tax losses, the expected amount of tax income into the state budget is ambiguous. In the case of new rules, the reality is that, if a company can amortize a tax loss up to only $50 \%$ of the tax base, it reduces its tax base by a lower part, which creates a higher tax liability. The new deduction rules in force since 2020 appear to be more advantageous for the state; however, it is not yet possible to assess their impact on corporate and tax indicators. This is because tax losses will be amortized over a longer period of time, and, ultimately, the taxpayer will amortize a higher tax loss compared to the rules in force until 2019.

Within the member states of the European Union, the amortization of tax losses distinguishes between the form of carry-forward loss and carry-back loss. Carry-forward loss is present in most tax systems, whether or not there is a time limit on the deduction. Tax loss carry-forward can rise or fall over the time, depending on the profit or loss (De Waegenaere et al. 2003). Tax loss carry-forward is a valuable asset because it can potentially reduce a company's future tax payments. However, there is 
often a great deal of uncertainty regarding the probability and timing of these tax savings. Sarkar (2013) suggests a contingent-claim model. The value is determined primarily by the size of accumulated carry-forwards relative to earnings. Author shows that, for poorly performing companies with a large tax loss carry-forward, the tax losses can account for a significant fraction of the company's equity value. "When the firm has a large amount of accumulated tax losses (relative to earnings), earnings growth rate is small, interest rate is high, and the firm is highly leveraged, the actual value of the tax loss carry-forward will be significantly smaller than the book value, and tax loss carry-forward will be a significant component of equity value" (Sarkar 2013, pp. 813-816). As Cooper and Knittel (2006, p. 652) state, "all OECD countries allow firms to carry tax losses forward in time: approximately two-thirds allow firms to carry losses forward from five to ten years; the remainder allow indefinite loss carry-forward. By contrast, only eight OECD countries allow firms to carry losses back to offset prior payments. In countries that allow carry-back tax losses may be the loss carried back between one and three tax years. Despite the fact that no tax system allows full loss refundability, the partial refund system has many well-known shortcomings." One of the reasons for the existence of a time limit is the difficult retention of information for a long time and the effort not to unnecessarily prolong the examination time of tax authorities for the legitimacy of carry-forward loss (Kagan 2020; Bührle and Spengel 2020; Post and Stals 2012). Carry-back loss leads to a lower tax liability for the tax period for which the loss was claimed, as there is a reduction in tax liability for the previous year. As a result of the retrospective application of the tax loss, the tax for the previous year may be refunded. Such a possibility is applied by only a few states and, in terms of time, mostly to one year before the year in which the tax loss was reported (Brante and Lejniece 2019; Kenton 2018). The arguments in favor of carry-back loss are based on the need to ensure tax neutrality and the principle of net taxation during the tax period. Carry-back loss allows viable businesses to continue to operate. The considerations against it relate to the administrative and budgetary interests of governments. From a fiscal point of view, there are difficulties in the amount of income reported in the state budget. Hypothetically, if several applications for a refund of previously paid taxes were made in one year and a decline in the economy was recorded, the shortfall in tax income would be even more serious for the country's economy (OECD 2011).

Another form of tax optimization appears to be the use of the taxpayer's beneficial status. From the point of view of existing tax subjects, from 2020 the Slovak Income Tax Act introduces a new concept called as a micro-taxpayer. It is a legal entity whose revenues do not exceed $€ 49,790$ in the tax period, which is the limit for the registration of the taxpayer for the purposes of payment of the value added tax. The deduction of tax loss here is not limited to $50 \%$ of the tax base. A micro-taxpayer can amortize a tax loss up to the amount of reported tax base. In case of claiming a tax loss, it is important to mention year 2014, which was also associated with the introduction of tax licenses. In that period, two institutes merged: depreciation of tax losses and tax licenses. A tax license is defined by taxpayer's annual turnover, differing for taxpayers and non-taxpayers. However, this is a tax, for which companies did not earn money. However, the chronological order caused problems in the final calculation of the tax liability, such that if the company did not amortize part of the tax loss in a given tax period, it lost the right to deduct it in the following tax period. Despite the fact that if the company wrote off its tax loss and the resulting tax fell to zero, it had to pay this minimum tax in the form of a tax license. The aim of tax licenses was to achieve a fairer taxation of companies that have long avoided paying taxes and a more equitable distribution of tax liability. One of the intentions of tax licenses was to abolish inactive companies and their subsequent erasure from the commercial register (Ministry of Finance of the Slovakia 2018; Kramarova et al. 2014).

In case of a broader effect of tax optimization in the form of changes in the stated factors, it is necessary to also look at the social and practical consequences of tax optimization. The existence of social factors, mainly those that focus on the social capital, social justice, tax morale, or confidence in tax legislation, lies in the psychology of the taxation effect. Kirchler et al. (2008) examined the confidence in taxes and their enforcement. Businesses are often motivated by either deference motives or by defiance 
motives (Braithwaite 2009). How is it possible to incorporate social aspects into individual analysis? This issue was addressed by Alm et al. (2012) and Mear et al. (2019). Alm (2014) looked at the issue of taxes in relation to social aspects and combined the group motivations of tax planning with the dynamic social context, which is motivated mainly by uncertainty. In case of further investigation, as reported by Mear et al. (2019), it is difficult to determine the further development of aspects impacting the deferred tax. The authors state that the prediction of the further development of the impact of tax optimization is influenced by a forecast error at level of $30 \%$. The predictive skills often appear to be inconsistent in the of collected data. The poor predictive skills are affected also by tax losses or changes in tax rates. Increasing forecast errors may also be affected by other factors.

\section{Conclusions}

The purpose of this article was to provide an information on how companies in Slovakia optimize their income tax with the ambition to maintain the achieved sales and profits at the highest possible level. To assess the use of tax optimization in the form of tax loss amortization, the theoretical part deals with the explanation of tax loss amortization in Slovakia and in the V4 countries and describes the situation in selected member states of the European Union. Tax loss is not a tool for tax optimization that would exist only in the conditions of the Slovak tax legislation. However, the method and also the time limit for deducting tax losses is heterogeneous between countries as well as periods. Legislative rules affect the amount of the amortized part of the tax base and the resulting tax liability. Their relationship to the total income tax arising from corporate income tax flowing into the state budget due to the large number of corporate, tax, and non-tax determinants cannot be unequivocally assessed. However, based on the assumptions and the analysis performed to examine the amortization of tax loss in Slovakia, the assumptions of the hypothesis that the amortization of tax losses in companies has an impact on the amount of tax liability and income tax paid can be considered as confirmed. However, the paper has some limitations. The individual descriptive statistics, analysis, and synthesis are limited by sample size, selection of variables, and data availability. In case of further research, it would be necessary to include other variables related to the aggressive tax planning and factors affecting the country's accounting. It would also be appropriate to break down the monitored sample of data into individual sectors, which would show which sector is most significantly affected by the amortization of tax losses. Therefore, the presented results are interpreted with caution. It is also important to mention that the observed time period includes the reactions of fiscal authorities in the form of business support to the shocks related to the economic crises in 2009 and 2011 in Slovakia and thus indirectly includes their interventions in the development. A future research as well as discussion could thus focus on the wider implications of applying the tax loss in a country, not only economically but also socially and practically, and at transnational, national, regional, or sectoral levels.

Author Contributions: All authors contributed equally to this article. All authors have read and agreed to the published version of the manuscript.

Funding: This research received no external funding.

Conflicts of Interest: The authors declare no conflict of interest.

\section{References}

Agarwal, Nipun, Paul Kwan, and David Paul. 2018. Merger and Acquisition Pricing Using Agent Based Modelling. Economics, Management, and Financial Markets 13: 84-99.

Alm, James. 2014. Individual versus group motivations in tax compliance decisions. In A Handbook of Alternative Theories of Public Economics. Edited by Francesco Forte, Ram Mudambi and Pietro M. Navarra. Cheltenham: Edward Elgar Publishing.

Alm, James, Erich Kirchler, and Stephan Muehlbacher. 2012. Combining psychology and economics in the analysis of compliance: from enforcement to cooperation. Economic Analysis Policy 42: 133-51. [CrossRef] 
Altshuler, Rosanne, Alan J. Auerbach, Michael Cooper, and Matthew Knittel. 2009. Understanding U.S. Corporate tax losses. Tax Policy and the Economy 23: 73-122. [CrossRef]

Alworth, Julian, and Giampaolo Arachi. 2001. The effect of taxes on corporate financing decisions: evidence from a panel of Italian firms. International Tax and Public Finance 8: 353-76. [CrossRef]

Armstrong, Christopher S., Jennifer L. Blouin, and David F. Larcker. 2012. The Incentives for Tax Planning. Journal of Accounting and Economics 53: 391-411. [CrossRef]

Australian Government. 2020. What is a tax loss? In Australian Tax Office; May 28. Available online: https: //www.ato.gov.au/General/losses/what-is-a-tax-loss-/ (accessed on 31 August 2020).

Bayrakdaroglu, Ali, Ilhan Ege, and Nusret Yazici. 2013. A Panel Data Analysis of Capital Structure Determinants: Empirical Results from Turkish Capital Market. International Journal of Economics and Finance 5: 131-40. [CrossRef]

Bazo, Ladislav, Miroslava Cukanova, Laura Markovicova, and Dusan Steinhauser. 2019. The Impact of Institutional Environment on Slovak Enterprises and the Institutional Hysteresis Effect. Journal of Competitiveness 11: 35-52. [CrossRef]

Benko, Jan. 2014. Odpočítavanie daňových strát od 1.1.2014. Podnikajte.sk. April 15. Available online: https://www.podnikajte.sk/dan-z-prijmov/odpocitavanie-danovych-strat-2014 (accessed on 20 August 2020).

Booth, Laurence, Varouj Aivazian, Asli Demirguc-Kunt, and Vojislav Maksimovic. 2001. Capital Structures in Developing Countries. The Journal of Finance 56: 87-130. [CrossRef]

Borg, Jeanette Calleja. 2013. The Tax Treatment of Losses under the Proposed Common Consolidated Corporate Tax Base Directive. Intertax 41: 581-87.

Bragg, Steven. 2018. Tax loss. Accountingtools.com. July 14. Available online: https://www.accountingtools.com/ articles/2017/5/15/tax-loss. (accessed on 20 August 2020).

Braithwaite, Valerie. 2009. Defiance in Taxation and Governance-Resisting and Dismissing Authority in a Democracy. Cheltenham and Northampton: Edward Elgar Publishing.

Brante, Ināra, and Ilona Lejniece. 2019. Tax Liabilities of the Board Member in Latvia: Legal-Economic Aspects. Economics and Culture 16: 93-105. [CrossRef]

Bührle, Anna Theresa, and Christoph Spengel. 2020. Tax Law and the Transfer of Losses: A European Overview and Categorization. Intertax 48: 564-81. [CrossRef]

Clausing, A. Kimberly. 2007. Corporate tax revenues in OECD countries. International Tax and Public Finance 14: 115-33. [CrossRef]

Cooper, Michael, and Matthew Knittel. 2006. Partial Loss Refundability: How Are Corporate Tax Losses Used? National Tax Journal 59: 651-63. [CrossRef]

De Waegenaere, Anja, Richard Sansing, and Jacco L. Wielhouwer. 2003. Valuation of a firm with a tax loss carryover. Journal of American Taxation Association 25: 65-82. [CrossRef]

Delcoure, Natalya. 2007. The Determinants of Capital Structure in Transitional Economies. International Review of Economics and Finance 16: 400-15. [CrossRef]

Demere, Paul, Michael P. Donohoe, and Petro Lisowsky. Forthcoming. The economic effects of special purpose entities on corporate tax avoidance. Contemporary Accounting Research. Published electronically 19 November. Available online: https://papers.ssrn.com/sol3/papers.cfm?abstract_id=3483644 (accessed on 20 August 2020).

Djankov, Simeon, Tim Ganser, Caralee McLiesh, Rita Ramalho, and Andrei Shleifer. 2010. The Effect of Corporate Taxes on Investment and Entrepreneurship. American Economic Journal: Macroeconomics 2: 31-64. [CrossRef]

Dyreng, Scott D., Michelle Hanlon, and Edward L. Maydew. 2008. Long-Run Corporate Tax Avoidance. The Accounting Review 83: 61-82. [CrossRef]

European Commission. 2017. Aggressive Tax Planning Indicators. Luxembourg: Publications Office of the European Union. [CrossRef]

Eurostat. 2020. Eurostat-Your Key to European Statistics. [Data file]. Available online: https://ec.europa.eu/eurostat/ data/database (accessed on 14 October 2020).

Fellingham, John. 2018. The Double Entry System of Accounting. Accounting, Economics and Law 8: 1-3. [CrossRef]

Finastat. 2020. Financial Information on Slovak Companies. [Data file]. Available online: https://www.finstat.sk/ (accessed on 14 October 2020).

Florescu, Nicu, Gheorghe Ciubotaru, and Lăcriţa N. Grigorie. 2016. The Difference between Accounting Amortization and Fiscal Amortization. Scientific Bulletin 20: 116-22. [CrossRef] 
Fox, William F., and LeAnn Luna. 2005. Do Limited Liability Companies Explain Declining State Corporate Tax Revenues? Public Finance Review 33: 690-720. [CrossRef]

Jim Yeub, Kim, and Shim Myungkyu. 2019. Does higher firm profit dispersion reflect greater micro uncertainty? Economics Letters 176: 35-38. [CrossRef]

Kagan, Julia. 2020. Tax Loss Carryforward. Investopedia.com. April 30. Available online: https://www.investopedia. com/terms/t/tax-loss-carryforward.asp (accessed on 20 August 2020).

Kenton, Will. 2018. Loss Carryback. Investopedia.com. May 14. Available online: https://www.investopedia.com/ terms/l/losscarryback.asp (accessed on 20 August 2020).

Khansalar, Ehsan, and Eilnaz Kashefi-Pour. 2020. The usefulness of the double entry constraint for predicting earnings. Review of Quantitative Finance and Accounting 54: 51-67. [CrossRef]

Kirchler, Erich, Erik Hoelzl, and Ingrid Wahl. 2008. Enforced versus voluntary tax compliance: the "slippery slope" framework. Journal of Economic Psychology 29: 210-25. [CrossRef]

Kosturikova, Ivana. 2016. Dependence of the effective taxation on the corporate income tax rate in the European union. Paper presented at the 14th International Scientific Conference: Economic Policy in the European Union Member Countries, Petrovice u Karviné, Czech Republic, September 14-16; Opava: Silesian University in Opava, pp. 314-22.

Krajňak, Michal. 2020. Analytic Hierarchy Process in Czech Taxpayers' Decision-Making Regarding their Tax Liability. Journal of Tax Reform 6: 142-56. [CrossRef]

Kramarova, Katarina, Elena Gregova, and Stefan Cisko. 2014. Changes in the corporate tax in Slovakia-tax license. Paper presented at the 8th International Scientific Conference on Business and Management, Vilnius, Lithuania, May 15-16; Vilnius: VGTU Press Technika, pp. 263-71.

Lisztwanova, Karolina, and Iveta Ratmanova. 2018. Assessment of Factors Influencing of Final Corporate Income Tax Liabilities in Selected Sectors in the Czech Republic. Paper presented at the 15th International Scientific Conference on European Financial Systems 2018, Brno, Czech Republic, June 25-26; Brno: Masaryk University, pp. 372-79.

Malikova, Olga, and Martina Cernikova. 2014. Financial management-Accounting and tax aspects of debt capital decision making. Paper presented at the SGEM2014 Conference Proceedings: International Multidisciplinary Scientific Conference on Social Sciences and Arts, Albena, Bulgaria, September 1-9; pp. 19-26. [CrossRef]

McGuire, Sean T., Stevanie S. Neuman, Adam J. Olson, and Thomas Omer. 2016. Do Investors Use Prior Tax Avoidance when Pricing Tax Loss Carryforwards? The Journal of the American Taxation Association 38: 27-49. [CrossRef]

Mear, Kim, Michael Bradbury, and Jill Hooks. 2019. The ability of deferred tax to predict future tax. Accounting $\mathcal{E}$ Finance. [CrossRef]

Ministry of Finance of the Slovakia. 2018. Zánik daňových licencií pripraví rozpočet o 115 mil. eur. January 1. Available online: https://www.mfsr.sk/sk/media/tlacove-spravy/zanik-danovych-licencii-pripravi-rozpocet-115-mileur.html?forceBrowserDetector=pc (accessed on 20 August 2020).

Modigliani, Franco, and Merton H. Miller. 1963. Corporate income taxes and the cost of capital: a correction. American Economic Review 53: 433-43.

Murray, Jean. 2019. Tax Loss Carry Forward Explained. The balances MB. July 15. Available online: https:// www.thebalancesmb.com/tax-loss-carryback-and-carry-forward-explained-398178 (accessed on 9 September 2020).

Nexia International. 2017. The International Tax Handbook. Haywards Heath: Bloomsbury Professional.

OECD. 2011. Corporate Loss Utilisation through Aggressive Tax Planning. Paris: OECD Publishing.

Olah, Judith, Sandor Kovacs, Zuzana Virglerova, Zoltan Lakner, and Jozsef Popp. 2019. Analysis and Comparison of Economic and Financial Risk Sources in SMEs of the Visegrad Group and Serbia. Sustainability 11: 1853. [CrossRef]

Pfeifer, Michael G., and Sae Jin Yoon. 2016. The ethical limits of tax planning. Trusts E Trustees 22: 159-65. [CrossRef]

Poddar, Satya. 1991. Refunding the Tax Value of Unutilized Losses. Policy Options for the Treatment of Tax Losses 5: $1-26$.

Post, R. Diane, and K. P. E. Stals. 2012. Tax Treatment of Corporate Losses: A Comparative Study. Intertax 40: 232-44. 
Sarkar, Sudipto. 2013. Valuation of tax loss carryforwards. Review of Quantitative Finance and Accounting 43: 803-28. [CrossRef]

Seneši, Norbert. 2020. Daňová optimalizácia za rok 2019 a v roku 2020. Podnikajte.sk. January 23. Available online: https://www.podnikajte.sk/dan-z-prijmov/danova-optimalizacia-za-rok-2019-v-roku-2020 (accessed on 9 September 2020).

Siekelova, Anna, Maria Kovacova, Peter Adamko, and Vojtech Stehel. 2019. Profit management as an instrument for SMEs developing: the case for Slovakia. Marketing and Management of Innovations 3: 285-96. [CrossRef]

Sion, Grațiela. 2018. How Artificial Intelligence Is Transforming the Economy. Will Cognitively Enhanced Machines Decrease and Eliminate Tasks from Human Workers through Automation? Journal of Self-Governance and Management Economics 6: 31-36. [CrossRef]

Statistical Office of the Slovak Republic. 2020. Business statistics. [Data file]. Retrieved from: http://datacube. statistics.sk/\#!/lang/sk (accessed on 14 October 2020).

Toder, Eric, and Alan Viard. 2016. A proposal to reform the taxation of corporate income. American Enterprise Institute and the Tax Policy Center. Available online: http://www.taxpolicycenter.org/publications/proposalreform-taxation-corporate-income (accessed on 9 September 2020).

Vanková, Lucia. 2018. Odpočet daňovej straty od základy dane právnickej osoby. Dane a účtovníctvo v praxi. Available online: https://www.daneauctovnictvo.sk/sk/casopis/dane-a-uctovnictvo-v-praxi/odpocetdanovej-straty-od-zakladu-dane-pravnickej-osoby.m-4427.html (accessed on 9 September 2020).

Zeng, Tao. 2010. Income tax liability for large corporations in China: 1998-2007. Asian Review of Accounting 18: 180-96. [CrossRef]

Publisher's Note: MDPI stays neutral with regard to jurisdictional claims in published maps and institutional affiliations.

(C) 2020 by the authors. Licensee MDPI, Basel, Switzerland. This article is an open access article distributed under the terms and conditions of the Creative Commons Attribution (CC BY) license (http://creativecommons.org/licenses/by/4.0/). 